\title{
PENYULUHAN HUKUM PERKAWINAN HINDU SEBAGAI STRATEGI MENUJU DESA SADAR HUKUM
}

\author{
I Putu Gelgel ${ }^{1}$, I Putu Sastra Wibawa ${ }^{2}$
}

\begin{abstract}
Legal awareness of Hindu marriage law that has not been maximal is a problem for the community in Tista Village, Busung Biu Subdistrict, Buleleng Regency. One of the strategies to increase the legal awareness of Tista Village community especially in understanding Hindu marriage law through legal education is done to achieve maximal legal awareness of the community. The Community Service Team succeeded in providing an understanding to the public about the importance of knowing the law of Hindu marriage. Hindu marriage counseling activities by combining lecture and case-case models can be a model of future counseling by no longer doing legal counseling with lecture models only.

Keywords: Legal Counseling, Hindu Marriage
\end{abstract}

\section{Pendahuluan}

Desa Tista merupakan salah satu Desa yang terletak di Kecamatan Busung Biu, Kabupaten Buleleng, tepatnya berada di Jalan Raya Pupuan, Kecamatan Busung Biu, Kabupaten Buleleng. Memiliki luas wilayah 912 ha dengan batas-batas antara lain; Bagian sebelah utara berbatasan dengan Desa Pucuk Sari, Bagian sebelah selatan berbatasan dengan Desa Manggis Sari, Bagian sebelah timur berbatasan dengan Desa Bongancina, dan bagian sebelah barat berbatasan dengan Desa Sepang.

Letak Desa Tista termasuk pedesaan, dengan jarak menuju Kecamatan sejauh 30 Km, jarak menuju Kabupaten sejauh 76 Km, dan jarak menuju Provinsi sejauh 100 Km. Desa Tista memiliki jumlah penduduk total 4.760 orang, dengan rincian jumlah penduduk laki-laki berjumlah 2.398 orang dan jumlah penduduk perempuan berjumlah 2.362 orang, untuk jumlah kepala keluarga berjumlah 1.338 Keluarga. Mayoritas penduduk Desa Tista memiliki mata pencaharian sebagai petani, dengan ditunjang dengan usaha perkebunan kopi, cengkeh, kalao serta perternakan dengan usaha ternak kambing, sapi, dan ayam. Sebagai sarana penunjang pendidikan, Desa Tista memiliki 1 unit Taman Kanak-kanak, 4 unit Sekolah dasar, dan 1 unit Sekolah

\footnotetext{
${ }^{1}$ Dosen Program Studi Hukum Agama Hindu, UNHI

${ }^{2}$ Dosen Program Studi Hukum Agama Hindu, UNHI
} 
Menengah Pertama. Untuk penunjang kesehatan, Desa Tista memiliki 1 unit Polindes dan 4 unit Posyandu.

Kegiatan adat istiadat di Desa Tista ditunjang oleh 3 Desa Pakraman, yakni Desa Pakraman tista, desa Pakraman Munduk Tengah, dan desa pakraman Munduk Mengenu. Serta memiliki 3 Banjar Adat, yakni Banjar Adat Tista, Banjar Adat Munduk Tengah, dan Banjar Adat Munduk Mengenu. Sedangkan untuk urusan administrasi kependudukan Desa Tista ditunjang juga oleh 3 Desa Dinas, yakni Desa Dinas Tista, Desa Dinas Munduk Tengah, dan Desa Dinas Munduk Mengenu.Organisasi kepemudaan di Desa Tista ditunjang oleh 3 unit karang taruna.

Berdasarkan hasil penelitian awal dan wawancara dengan perwakilan warga masyarakat Desa Tista, hampir semua lapisan masyarakat belum memahami akan pentingnya hukum perkawinan Hindu bagi mereka. Sehingga target dari kegiatan pengabdian masyarakat ini adalah 1) Meningkatkan pemahaman masyarakat akan pentingnya pemahaman terhadap hukum perkawinan Hindu, 2) Memberikan pelatihan kepada masyarakat untuk dapat menyelesaikan permasalahan seputar hukum perkawinan Hindu, dan 3) Membentuk kelompok masyarakat sadar hukum di Desa Tista sebagai kelompok terdepan untuk membantu memecahkan persoalan yang menyangkut hukum perkawinan Hindu dibawah binaan dari program studi hukum agama Hindu, Universitas Hindu Indonesi Denpasar.

\section{Metode Pelaksanaan}

Kegiatan pengabdian masyarakat dilakukan dengan khalayak sasaran antara lain: tokoh adat, tokoh agama, Pemangku, sekaa truna, Ibu-Ibu PKK, serta masyarakat adat di Desa Tista.

Metode yang digunakan dalam pelaksanaan kegiatan pengabdian masyarakat adalah penyuluhan hukum, simulasi kasus, pelatihan dan pendampingan. Kegiatan tahap pertama yakni melakukan penyuhan hukum perkawinan Hindu kepada masyarakat Desa Tista, kemudian dilanjutkan dengan kegiatan tahapan kedua yakni melakukan simulasi kasus yang menyangkut hukum perkawinan Hindu dan tahapan ketiga yakni melakukan pelatihan dan pendampingan kepada kelompok masyarakat yang ditunjuk sebagai kelompok binaan dari program studi hukum agama Hindu, Universitas Hindu Indonesia Denpasar. 


\section{Hasil dan Pembahasan}

Penyuluhan hukum perkawinan Hindu dilakukan pada tanggal 8-9 November 2017 dengan pembagian tugas, antara lain: Prof. Dr. I Putu Gelgel, S.H.,M.Hum bertugas memberikan penyuluhan hukum perkawinan Hindu, sedangkan I Putu Sastra Wibawa, S.H.,M.H bertugas melakukan pendampingan dalam pembahasan kasus yang terkait hukum perkawinan Hindu dan melakukan pelatihan serta pendampingan kepada kelompok masyarakat Desa Tista. Masyarakat Desa Tista yang mengikuti pelatihan sebanyak 250 orang.

Penyuluhan hukum adakah kegiatan untuk meningkatkan kesadaran hukum masyarakat berupa penyampaian dan penjelasan peraturan hukum kepada masyarakat dalam suasana informal agar setiap masyarakat mengetahui dan memahami apa yang menjadi hak, kewajiban dan wewenangnya, sehingga tercipta sikap dan prilaku berdasarkan hukum, yakni disamping mengetahui, memahami, menghayati sekaligus mematuhi /mentaatinya. Penyuluhan hukum dapat dilakukan melalui dua cara : pertama, penyuluhan hukum langsung yaitu kegiatan penyuluhan hukum berhadapan dengan masyarakat yang disuluh, dapat berdialog dan bersambung rasa misalnya : ceramah, diskusi, temu, simulasi dan sebagainya. Kedua, penyuluhan hukum tidak langsung yaitu kegiatan penyuluhan hukum yang dilakukan tidak berhadapan dengan masyarakat yang disuluh, melainkan melalui media/perantara,seperti : radio, televisi, video, majalah, surat kabar, film,dan lain sebagainya.

Membangun kesadaran hukum bagi masyarakat tidaklah mudah, sebab tidak semua orang memiliki kesadaran tersebut. Hukum sebagai fenomena sosial merupakan institusi dan pengendalian masyarakat. Di dalam masyarakat dijumpai berbagai institusi yang masing-masing dibutuhkan di dalam masyarakat untuk memenuhi kebutuhannya dan memperlancar jalannya pemenuhan kebutuhan tersebut, oleh karena fungsinya demikian masyarakat perlu akan kehadiran institusi sebagai pemahaman kesadaran hukum. Kesadaran hukum adalah kesadaran yang terdapat pada setiap manusia tentang apa itu hukum dan apa seharusnya hukum itu. Menurut Scolten, bahwa kesadaran hukum merupakan suatu kategori tertentu dari hidup kejiwaan kita dengan mana kita membedakan antara hukum dan bukan hukum serta antara yang seyogyanya dan tidak seyogianya untuk dilakukan. Peningkatan 
kesadaran hukum seyogiyanya dilakukan melalui penerangan dan penyuluhan hukum yang teratur atas dasar perencanaan yang mantap.Penyuluhan hukum bertujuan agar masyarakat mengetahui dan memahami hukum-hukum tertentu ${ }^{3}$.

Kesadaran hukum itu sebenarnya meerupakan kesadaran akan nilai-nilai yang terdapat di dalam diri manusia, tentang hukum yang ada atau tentang hukum yang diharapkan ada. Sebetulnya yang ditekankan adalah nilai-nilai tentang fungsi hukum dan bukan suatu penilaian (menurut) hukum terhadap kejadian-kejadian yang konkrit dalam masyarakat yang bersangkutan. Upaya untuk mengubah budaya yang sudah ada pada masyarakat indonesia sebenarnya sangat susah, karena culture yang ada di indonesia itu sangat bermacam-macam dan beraneka ragam, sangat tidak mungkin untuk mengubahnya. Tetapi kaitannya dengan budaya masyarakat indonesia yang sangat kurang terhadap kesadaran hukum itu mungkin disebabkan karena dari awal masyarakat itu tidak mengerti akan pentingnya hukum bagi kehidupan, kalau saja tidak ada hukum mungkin akan terjadi kekacauan dimana-mana. Untuk dapat meningkatkan kesadaran hukum di masyarakat mungkin pemerintah atau aparat penegak hukum sebagai pembuat dan pelaksana dapat lebih mensosialisasikan hukum itu sendiri kepada masyarakat. Agar masyarakat dapat lebih mengerti mengenai akan pentingnya hukum itu bagi kehidupan bermasyarakat. Jadi upaya untuk mengubah culture yang ada di masyarakat itu harus diawali dengan pensosialisasian yang lebih mendalam dan terarah terhadap masyarakat mengenai pentingnya hukum bagi kehidupan, dengan semakin banyaknya masyarakat yang mengerti akan pentingnya hukum, budaya masyarakat kita sedikit demi sedikit akan berubah menjadi lebih baik dan kesadaran hukum masyarakat indonesia akan lebih meningkat. Dan tujuan dari hukum akan tercapai yaitu masyarakat yang aman, tentram dan sejahtera. Dalam kegiatan pengabdian masyarakat di Desa Tista, penyuluhan hukum dilakukan secara langsung. Penyuluhan hukum bertujuan untuk mencapai kesadaran hukum yang tinggi dalam masyarakat, sehingga setiap anggota masyarakat menyadari hak dan kewajibannya sebagai warga Negara, dalam rangka tegaknya hukum, keadilan,

\footnotetext{
${ }^{3}$ R. Soeroso., 2004, Pengantar Ilmu Hukum, Sinar Grafika, Jakarta, hlm.32
} 
perlindungan terhadap harkat dan martabat manusia, ketertiban, ketentraman, dan terbentuknya perilaku warga negara yang taat pada hukum.

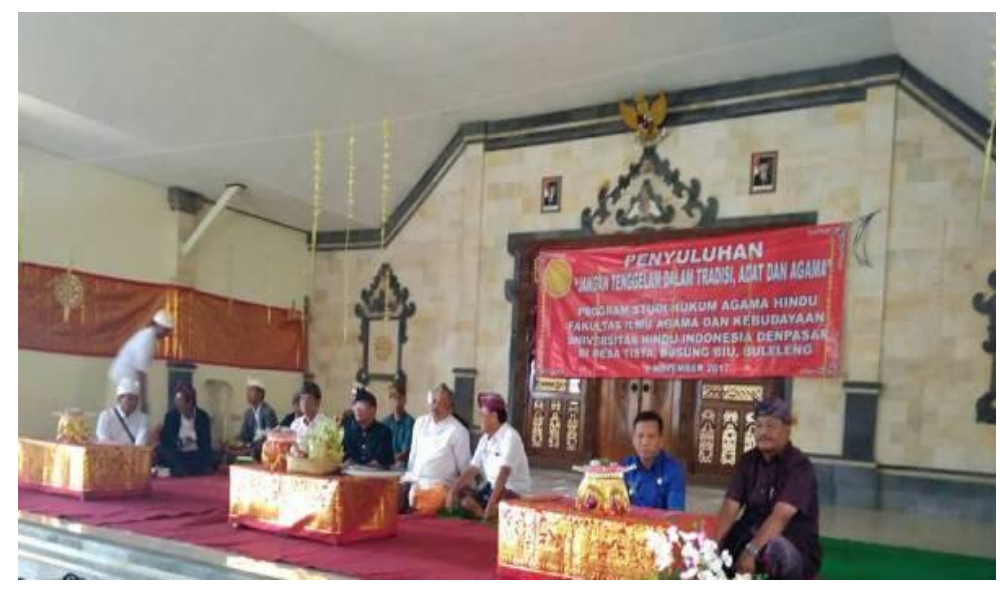

Gambar 1.1 Kegiatan Penyuluhan Hukum di Desa Tista

Materi penyuluhan hukum perkawinan Hindu yang diberikan kepada masyarakat antara lain: mengenai syarat sah nya hukum perkawinan Hindu menurut UndangUndang Republik Indonesia Nomor 1 Tahun 1974 tentang Perkawinan, Peraturan Pemerintah Republik Indonesia Nomor 9 Tahun 1975 tentang Pelaksanaan UndangUndang Perkawinan, serta hukum Hindu dan Hukum adat Bali. Dijelaskan pula dalam penyuluhan hukum tersebut bahwa hukum perkawinan Hindu setidaknya hukum perkawinan Hindu menjalin beberapa perikatan, yakni perikatan perdata, perikatan keluarga, dan perikatan agama. Selain hal itu, masyarakat Desa Tista juga diberikan pemahaman mengenai larangan perkawinan menurut hukum Hindu, Pemahaman mengenai istilah perceraian dan poligami menurut hukum Hindu, serta memberikan pemahaman mengenai kewajiban suami, kewajiban istri, dan kewajiban anak.

Peserta penyuluhan secara sungguh-sungguh mengikuti seluruh acara kegiatan. Ini dibuktikan pada saat sesi tanya jawab banyak masyarakat yang mengacungkan tangan, sampai waktu yang diberikan tidak mencukupi sehingga diminta untuk menuliskan daftar pertanyaannya.

Kegiatan pengabdian masyarakat dilanjutkan dengan kegiatan bedah kasus hukum perkawinan Hindu. Kegiatan ini diawali dengan pembagian kelompok terhadap masyarakat yang hadir saat acara tersebut, beberapa kelompok yang terbentuk kemudian diberikan beberapa contoh kasus terkait hukum perkawinan Hindu untuk 
dibedah atau dicarikan solusi jalan keluarnya dengan bekal pemahaman materi penyuluhan hukum perkawinan yang diberikan sebelumnya. Solusi yang didapat kemudian masing-masing kelompok merumuskannya dalam bentuk narasi. Setelah waktu yang diberikan habis, maka perwakilan kelompok membacakan hasilnya secara bergiliran. Hasil pembahasan kasus dari kelompok kemudian di tanggapi oleh narasumber yang bertugas untuk itu. Kegiatan ini bertujuan untuk melatih masyarakat, baik secara individu maupun kelompok untuk menyelesaikan persoalan terkait dengan hukum perkawinan Hindu dengan mengedepankan prinsip win-win solution. Artinya diupayakan mencari jalan terbaik dalam penyelesain masalah tersebut.

Berbagai kegiatan pengabdian masyarakat tersebut telah mampu memberikan sumbangsih kepada masyarakat Desa Tista, dimana masyarakat Desa Tista telah mampu memahami hukum perkawinan Hindu kemudian mampu baik secara kelompok maupun secara individu menyelesaikan kasus-kasus yang terkait dengan hukum perkawinan Hindu kemudian membuat narasinya.

\section{Penutup}

\section{Simpulan}

Simpulan dari kegiatan pengabdian kepada masyarakat ini dengan khayalak sasaran masyarakat Desa Tista adalah 1) Penyuluhan hukum menjadi solusi dalam meningkatkan kesadaran hukum masyarakat Desa Tista dalam bidang hukum perkawinan Hindu, 2) Metode bedah kasus sangat efektif dalam meningkatkan pemahaman masyarakat Desa Tista dalam bidang hukum perkawinan Hindu, dan 3) Masyarakat Desa Tista telah mampu memahami hukum perkawinan Hindu kemudian mampu baik secara kelompok maupun secara individu menyelesaikan kasus-kasus yang terkait dengan hukum perkawinan Hindu

\section{Rekomendasi}

Mengingat kegiatan penyluhan hukum perkawinan Hindu sangat bermanfaat bagi masyarakat untuk meningkatkan kesadaran hukum dalam bidang hukum perkawinan Hindu maka dipandang perlu untuk selanjutnya dibentuk Desa Sadar Hukum Perkawinan yang kemudian menjadi Desa Binaan yang secara berkesinambungan mendapatkan pendampingan dari pihak terkait. 


\section{Ucapan Terima Kasih}

Terima kasih kepada Direktorat Jenderal Bimbingan Masyarakat Hindu, Kementerian Agama, Republik Indonesia yang telah memfasilitasi dan mendanai kegiatan pengabdian kepada masyarakat ini. Penulis juga mengucapkan terima kasih yang sebesar-besarnya kepada masyarakat Desa Tista serta semua pihak yang mendukung dalam kegiatan ini.

\section{Daftar Pustaka}

Aveldoorn, Van. 1996. Pengantar Ilmu Hukum. Jakarta : PT.Pradanya Paramita.

Tutik, Titik Triwulan. 2006. Pengantar Ilmu Hukum. Surabaya: PT. Prestasi Pustaka.

R. Soeroso., 2004, Pengantar Ilmu Hukum, Sinar Grafika, Jakarta 